UDC 349.6(497.11); 502.14(497.11)

CERIF: S120

\author{
Mirjana Drenovak-Ivanović, $\mathrm{PhD}^{*}$
}

\title{
ENVIRONMENTAL IMPACT ASSESSMENT IN SERBIAN LEGAL SYSTEM: CURRENT ISSUES AND PROSPECTS FOR REVISION
}

This paper analyses current issues regarding the environmental impact assessment procedure (hereinafter: EIA). The author analyses the legal nature of the decisions made in the EIA procedure and points out the problems which in practice raise the question of whether an EIA should be organized as three independent administrative proceedings or as one comprehensive procedure. In answering the question of whether the appeal is an effective legal remedy in the EIA procedure, special attention was paid to the analysis of the practice of the Administrative Court and the Constitutional Court of Serbia. In the concluding observations, the author points out preconditions for the establishment of a new EIA system.

Key words: $\quad$ EIA. - Effectiveness of Appeals in EIA. - Legal Nature of Decisions in EIA. - Extraordinary Legal Remedies and Environmental Protection. - Temporary Measures and Environmental Protection.

\section{INTRODUCTION}

EIA is a procedure which determines the environmental impact of projects that are planned or executed, whether there are alternative solutions and the possibility of applying technology that would have a more favourable environmental impact and whose measures can be applied in order to prevent, mitigate or eliminate adverse environmental impacts. ${ }^{1}$ It ius.bg.ac.rs.

* Assistant Professor, University of Belgrade Faculty of Law, mirjana.drenovak@

1 EIA is forcing "truly revolutionary changes upon traditional administrative processes (...) it informs administrators, project initiators, and third parties and provides them with an opportunity to require fuller integration of environmental concerns into the 
is a special administrative procedure that aims to achieve a preventive environmental protection. ${ }^{2}$

The first codification of the EIA procedure, which introduced important changes to the administrative decision-making process, we find in the law of the United States of America - the National Environmental Policy Act, adopted in $1969 .^{3}$ A demand for establishing a special EIA procedure was recognised shortly in comparative law, which led to introducing particular laws on EIA: in Canada in 1973, Australia in 1974, Germany in 1975 and in France in $1976 .{ }^{4}$ A unique EIA procedure is a part of the environmental acquis since 1985, when Directive on the Assessment of the Effects of Certain Public and Private Projects on the Environment was adopted in 1991, UN Economic Commission for Europe adopted Espoo Convention on EIA in a Transboundary Context, and in 1992 the requirement of implementation of EIA was adopted as the 17th principle of the Rio Declaration on Environment and Development. Public participation and legal protection in environmental matters, which are applied in the EIA procedure, are prescribed in the Aarhus Convention (hereinafter: AC) as well.

By ratifying the AC, Serbia committed to provide "efficient, equitable, fair and timely" legal protection in matters of importance to the environmental protection. ${ }^{5}$ Eleven-year practice of applying Law on EIA $^{6}$ in Serbia has revealed a large number of deficiencies of the procedure, ${ }^{7}$ which raises many questions: what is the legal nature of the decisions made in the first and second stage of the EIA; what are legal consequences of the obligation to deliver the decisions to certain parties in the procedure, while remaining parties are being informed of the decisions; whether informing the public as stipulated by the Law on EIA is the same as informing stipulated by General Administrative Procedure

decision-making process". N. de Sadeleer, Environmental Principles: From Political Slogans to Legal Rules, OUP, 2002, 87-89.

2 See: E. Fisher et al., Environmental Law, OUP, 2013, 847-850.

3 See: R. J. Lazarus, The making of Environmental Law, University of Chicago Press, 2008, 67-80; J. F. Benson, "What is the alternative? Impact assessment tools and sustainable planning", Impact Assessment and Project Appraisal 4/2003, 261-280.

4 K. Miller, A. Rawson, Act Environmental Law, Canberra, 2009, 43-44.

5 See: Art. 9, para. 4 of the AC

6 Law on Environmental Impact Assessment, Official Gazette of the Republic of Serbia Nos. 135/04, 36/09.

7 In its Report for 2015, the European Commission stated that no progress could be reported on horizontal legislation and that additional efforts are required to boost capacity for effective public participation and consultation in the environmental decisionmaking. Serbia 2015, Communication from the Commission to the European Parliament, the Council, the European Economic and Social Committee and the Committee of the Regions, Brussels, SWD(2015) 211 final, p. 66. 
Act (hereinafter: GAPA) ${ }^{8}$ in what manner the two instance principle and devolution are provided in resolving the appeal; whether the appeal is an effective legal remedy in an EIA procedure set in that manner; whether the application of suspensory effect of the complaint (in accordance with Art. 23 of the Administrative Disputes Act - hereinafter: $\mathrm{ADA}^{9}$ ) provides a basis for "adequate and efficient" temporary measure, in accordance with Art. 9 para. 4 of the AC; whether the request for the court decision review, as an extraordinary legal remedy, can be considered an adequate substitute for the cases which stipulate finality of first instance administrative decision-making in environmental matters.

The paper aims to portray, by analysing the basic elements of the EIA and the existing administrative and judicial practices, the distinctiveness of this administrative procedure and provide answers to questions which arise.

\section{BASIC PRINCIPLES OF THE EIA PROCEDURE}

For the purpose of further analysis, firstly we shall identify the basic steps of conducting an EIA procedure in Serbia's judicial system.

The EIA is carried out for projects in the fields of industry, mining, transport, tourism, agriculture, forestry, water management, waste management and utilities, as well as for projects that are planned in protected natural areas and in protected surroundings of an immovable cultural property. The EIA is conducted in three stages. In the first stage the decision is made on the need for conducting EIA, in the second stage the scope and contents of the EIA is determined, and, in the third stage, it is decided on the approval of the EIA study. The projects which require the EIA are provided in a separate List. ${ }^{10}$ This means that the first stage does not apply for these projects. The national legal framework contains a List

8 General Administrative Procedure Act, Official Gazette of the Republic of Serbia No. 30/10.

9 Administrative Disputes Act, Official Gazette of the Republic of Serbia No. $111 / 09$.

10 Those are projects for the construction of: oil processing plants, power plants for production of $50 \mathrm{MW}$ of electricity and more, nuclear reactors and facilities for processing spent nuclear fuel, chemical plants, major railways and reconstruction of main highways, airports with a runway longer than $2.100 \mathrm{~m}$, inland waterways with international or bilateral regime of navigation, hazardous waste treatment plants, plants for the treatment of non-hazardous waste capacity of more than $70 \mathrm{t}$ per day, exploitation of groundwater, with an annual capacity of more than 10 million $\mathrm{m}^{3}$ exploited or recharged water and the like. See: Decree on establishing the List of projects for which the impact assessment is mandatory and the List of projects for which the EIA can be requested, $O f$ ficial Gazette of the Republic of Serbia No. 114/08. 
of projects for which an impact assessment may be required, and for which implementation of the first stage is mandatory. ${ }^{11}$ For other projects the EIA is not conducted.

In the first stage, the competent body shall inform the authorities, organizations and the public concerned on the request submitted for deciding on the need for EIA within ten days of receipt of the request. Thereafter, the above entities have the right to express an opinion on the proposed project. The competent authority shall decide on the request on the basis of particularity and location of the project, as well as voiced opinion of authorities, organizations and the public concerned. The project owner and the public concerned may lodge an appeal against his ruling.

The second stage involves defining the scope and contents, i.e. providing a framework of the EIA study. At this stage, the project owner discloses the information about the project, presents the main alternatives which he considered, and the most important reasons for reaching a decision, describes the environmental factors susceptible to risk due to the implementation of the project, describes possible short- and long-term environmental impacts of the project and measures for prevention, mitigation or elimination of any adverse environmental impact. ${ }^{12}$ Based on above facts and opinions of authorities, organizations and the public concerned, the competent authority shall decide on the scope and contents of the EIA study, i.e. whether the study analyses e.g. only the impact of operation of the plant, or the construction and operation of the plant; whether the study considers the impact of the planned project on the local level or the global impact as well, etc. The project owner and the public concerned may lodge an appeal against this ruling.

In the third stage, a decision is made on approval of the EIA study. Only authorized organizations registered in a special register may conduct an EIA study. An EIA study evaluates quality of environmental factors and their sensitivity within areas of planned activities, foresees the direct and indirect adverse impacts of the project on environmental factors as well as measures and conditions for mitigation and elimination of adverse impacts. A competent authority shall decide on approval or denial of the request for approval of the EIA study by considering the opinion of special committee for technical verification. The reviewing committee issues a report containing professional assessment of the EIA study and draft decision, after analysing the EIA study and the report with a

11 Decree on establishing the List of projects for which the impact assessment is mandatory and the List of projects for which the EIA can be requested, Official Gazette of the Republic of Serbia No. 114/08.

12 See: Rulebook on the contents of requests for the necessity of impact assessment and on the contents of requests for specification of scope and contents of the EIA study, Official Gazette of the Republic of Serbia No. 69/05. 
systematised overview of the opinions of authorities, organizations and the public concerned. ${ }^{13}$ The decision of the competent authority is final, which means that in the third stage the applicant and the public concerned do not have the right to appeal against the ruling, but only to initiate an administrative dispute.

The competent authority has the obligation to deliver the decisions made at all stages of EIA only to the project owner. In accordance with the Law on EIA, authorities, organizations and the public concerned are "informed" about these decisions, as stated in the Law on EIA (Art. 10 para. 7, Art. 14 para. 4, Art. 24 para. 1 and Art. 25).

Only upon the approval of the EIA study, which is obtained in the final, third stage of the EIA, the project owner may start with the implementation.

\section{THE RIGHT TO APPEAL AND COMPLAINT IN THE EIA PROCEDURE}

\subsection{Decisions in the EIA Procedure as Subjects of Appeal and Complaint}

The first two questions that arise are: what is decided in each stage of the EIA and what can be subject to appeal? In the first stage, it is decided on whether it is necessary to conduct EIA. It means that, based on the material enclosed by the operator and an opinion of authorities, organizations and the public concerned, the competent authority evaluates whether the potential impact of the facility on human health and the environment is such that it requires further examination through EIA study or not. In addition, in the decision stating that it is not necessary to conduct an EIA the competent authority may determine the minimum requirements for environmental protection. In that case, the project owner may appeal to challenge the measures imposed. ${ }^{14}$ If a decision stipulates

13 Rulebook on work of technical committee for EIA study, Official Gazette of the Republic of Serbia No. 69/05.

14 See: Decision of the City of Belgrade, Secretariat for Environmental Protection, No. 501.4-15/2012-V-04, dated 27 February 2012. The decision reads that it is not necessary to perform EIA for the project of constructing radio base stations for mobile telephony. The same decision stipulated that the project owner may start executing the project, as long as conditions and safeguards, which are listed, are applied in the construction and in regular use of the building. In one case, the Administrative Court considered whether the ordered measures are adequate and whether the complainant provided adequate legal protection against further activities. The Administrative Court held that the project owner shall ensure the execution of the programme of continuous monitoring of air quality, noise, waste water, the quality and the total amount of bio-compost and waste management in accordance with the applicable regulations, which is specifically defined in the 
that the EIA is not required, the project owner may start with the implementation. If a decision stipulates the necessity of EIA, the project owner is referred to the second and third stage of the EIA. In both cases, the public concerned may lodge an appeal if they are not allowed to participate in the proceedings or if they consider that the opinions expressed were not taken into account. ${ }^{15}$ Initiation of an administrative dispute does not prevent moving on to the next stage.

The competent authority's decision of EIA study approval is final administrative act. This ruling cannot be appealed, but the applicant and the public concerned are able to institute an administrative dispute. There are no restrictions in terms of participation of the public concerned. Therefore, even if they did not participate in the first two stages of the procedure, the public concerned may submit a complaint.

The question then arises as to which acts of administrative authorities issued in the third stage of the procedure can, in fact, be disputed. The first such act is Report of the technical committee, which must be

part of the decision on giving approval in the section "program of monitoring the environmental impact". The project owner is obliged to submit the data to the Agency for Environmental Protection, City Administration for Environmental Protection and the City Administration for Inspection. This further means that the complainant can protect their rights and interests in the future, because in the event that the project owner fails to comply with the project plan for the implementation of prescribed measures, the complainant may address the competent inspections for environmental protection. See: The ruling of the Administrative Court ZU. 15891/10 (2009) of 19 January 2012.

15 In the case of III-5 U.13200/11 of 13 March 2014 the Administrative Court considered the justification of the complaint filed against the decision of the City Secretariat of Environment, which rejected the petitioner's appeal against the decision of the City Administration for Environmental Protection, which read that EIA is not necessary in the project of setting base stations for mobile telephony in a particular location, since projects for base stations of such strength do not require EIA. The Administrative Court expressed the opinion that the appeal should have been heard. When the base station undeniably has users, other than the person concerned, with their antenna systems of different strengths, it is the obligation of administrative authorities to assess the impact of the base station with all installed systems as a whole. The Court, in this case, took into account the doctor's opinion that the petitioner's son's health problems were caused by negative radiation in the environment. According to the interpretation of the Court, "in such a situation, the assessment of the harmful effects of base station as one of the possible sources of disease of the petitioner's household member is necessary, regardless of the defendant's allegations that it is on the List of projects II of the Decree, for which it is not necessary, but possible to conduct EIA". The Trial Chamber of the Administrative Court referred to the practice of ECHR in the reasons for judgment alleging that "assessing environmental impact at the request of the petitioner and her family represents an element of her right to respect for private and family life as stated in Article 8 of the European Convention for the Protection of Human Rights, and addressed by the Strasbourg court in the case Dubecka v. Ukraine (application no. 30499/03), which obliges the national authorities to take all measures in the environmental protection of the applicant." See: Jelena Tišma, "Upravno-sudska zaštita prava na zdravu životnu sredinu", Bilten Vrhovnog Kasacionog suda, 2/2015, 327-337. 
presented in detail by the competent authority in the explanation of the decision on the EIA. In that sense, the complaint can point to shortcomings identified in the report and request amendments or a new EIA study. ${ }^{16}$ Here we point to the significant shortcomings of the Law on EIA. After the public opinion is acquired, the competent authority may prescribe certain amendments to the EIA study. However, the Law on EIA does not provide the possibility for the public concerned to express their opinion on the amended EIA study. That prevents the possibility to determine whether the amendments to the EIA study were carried out in accordance with the opinions expressed, which would enable further amendment of the EIA study in the administrative procedure, and, here as well, provides only the possibility of an administrative dispute.

The second document is the Notice which the competent authority issues in order to inform the authorities, organizations and the public concerned about the contents of the decision on the EIA, the main reasons on which it is based and the most important measures that the project owner is obliged to undertake. The legal nature of the Notice in the Law on EIA will be further discussed in section 4.1.

3.2. Shall the party have the right or the ability to pursue the procedure when the decision is made in the first and second stage of the EIA?

A final administrative act passed in the first and second stages represents a basis for the issuance of an administrative act in the third stage. ${ }^{17}$ The question that arises is: what does a party gain by the decision about need for EIA and the decision on the scope and content of the EIA study? The conducted analysis shows that the party does not obtain the right applicable separately from the EIA procedure. An issue here is a need to establish what it is that precedes the decision on approval of the EIA study. ${ }^{18}$

An illustrative example of the legal nature of the decisions made at various stages of proceedings can be found in the Decision of the Constitutional Court of Serbia on compliance of certain provisions of the Law

16 In a complaint regarding the approval of the EIA study for the construction of a hydropower plant, the complainant requested a new study, explaining that the alternative solutions were not analysed to a sufficient extent, particularly bearing in mind that the planned project covers the territory of several protected natural resources. In the same complaint, it was pointed to the need that the new study is based on updated information relating to the state of the environment in the area of planned project. See: The case file to the Ministry of Environment and Spatial Planning of Serbia No. 353-02-01396/201002. See: M. Drenovak-Ivanovic, "The Development of the Right to Public Participation on Environmental Matters as a New Concept of Administrative Decision Making in Serbia”, Transylvanian Review of Administrative Sciences 44/2015, 74-90.

17 See: Art. 16, para. 3 of the Law on EIA.

18 See: Art. 192, para 1 of the GAPA. 
on Expropriation with the Constitution. ${ }^{19}$ Explaining the decision, the Constitutional Court established that the expropriation procedure, in fact, consists of two stages. In the first stage, a special law or decision is issued by the Government in order to define the public interest, and in the second stage an act of expropriation is adopted, which legitimates the exemption of certain immovable property from former owner's property rights. The Decision of the Constitutional Court reads that "the decree of the Government which adopts the proposal for the establishment of public interest does not formally and legally restrict or deprive the immovable property owner of his property rights, but it introduces a legal presumption of exempting certain immovable property from property rights of the former owner" 20 . Having in mind the earlier analysis of the legal nature of the decision in the EIA, the same principle can be applied to the EIA procedure: the decision in the first and second stage creates a legal presumption for the decision-making on the EIA study.

That raises the further question as to whether it is considered that the facts are established if the final administrative act is passed in the first or second stage of the EIA, or this act has to be final judgement passed by the Administrative Court? The answer to this question requires an analysis of the effectiveness of the right to appeal to the EIA, which will be discussed in section 4 .

\section{THE EFFECTIVENESS OF EXERCISING THE RIGHT TO APPEAL IN THE EIA}

An analysis of the effectiveness of exercising the right to appeal in the EIA requires in-depth consideration of the following matters: the manner of delivering the decisions to the parties in the EIA procedure and whether informing as stipulated by the Law on EIA is the same as informing stipulated by GAPA; in what manner the principle of two instances is provided in resolving an appeal and what is the jurisdiction of the Administrative Commission of the Government of the Republic of Serbia; whether the absence of two-level decision-making in cases where an appeal is excluded can be mitigated by using an extraordinary remedy.

\subsection{Delivery in the EIA Procedure}

A matter of delivering acts, adopted by the competent authority in three stages of the procedure, has an important role in the implementation of the EIA procedure. The competent authority delivers decisions to the

19 Decision of the Constitutional Court of Serbia, IУ $3-17 / 2011$ dated 23 May 2013.

20 Decision of the Constitutional Court of Serbia, IУ 2013. 
project owner at all stages of the EIA, and "informs the authorities, organizations and the public concerned" about them. Bearing in mind that the EIA procedure is bipartisan and the public concerned has the status of a party to the proceedings, it is necessary to point out the legal nature of procedural steps taken in order to acquaint the public concerned with the contents of the adopted legislation.

Notifying, in terms of GAPA, is a procedural action in accordance with which the party, the third party and the authority have the right to be informed of the proceedings. ${ }^{2}$ "Notification" stipulated by the Law on EIA cannot be understood in this manner. "Notification" stipulated by the Law on EIA may be in some way similar, but not equal to the concept of delivery by public announcement, as a special form of delivery in exceptional circumstances. Bearing in mind that the public concerned has the right of appeal, or complaint, regarding the decisions made, and that the delivery is crucial for calculating the deadlines, "notifying" the public concerned should be understood as "delivering" in the sense of GAPA, i.e. as a procedural action. ${ }^{22}$ Otherwise, it may occur that the public concerned is precluded in this right, without any knowledge that an act was adopted, which would have a negative impact on the effectiveness of the right to appeal. Explaining the decision, which also raised a question of the constitutionality of a legislative solution to consider the decision, adopting a proposal for establishing the public interest for expropriation of certain immovable property, delivered to the parties in the proceedings at the moment of its publication, the Constitutional Court, in one case, held that "the principle of availability of the legal remedy cannot exist only on a theoretical level, and it is more important that the statutory remedy is actually available in practice in a particular period of time. (...) The available legal remedy against the decision on establishing the public interest - an administrative dispute, in essence, represents 'an illusory remedy', especially bearing in mind the prescribed manner of its delivery". ${ }^{23}$

\subsection{Principle of Two Instances and Devolution of the Appeal in the EIA}

The EIA procedure is conducted by the ministry in charge of environmental affairs for those projects which are approved by a republic authority. If the decision in the first instance is issued by the ministry, the Administrative Commission of the Government shall decide on the appeal.

21 Art. 70 par. 5 of GAPA.

22 See: Z. Tomić, Upravno pravo - sistem, Belgrade 20024, 379-380.

23 Decision of the Constitutional Court, $\mathrm{IУ}_{3}-17 / 2011$. 
According to the Rules of Procedure of the Government, ${ }^{24}$ only a member of the Government shall be the chairperson or a member of the Administrative Commission. (Art. 30 para. 2) The same Rules of Procedure stipulate that the ministry shall prepare a proposed act for the Government (Art. 36), where the proposed decision shall be prepared and submitted to the Government with a disposition and rationale (Art. 38). The question then arises whether, in case of an appeal, when a ministry is the first instance authority, the Law on EIA ensures devolution and fundamental two-instance decision-making on the appeal.

In order to answer this question, a wording that an official who resolves in administrative matters shall be excluded if he/she was involved in proceedings or adjudication in the first instance should be addressed. ${ }^{25}$ The participation of this person in the preparation of a decision of the Administrative Commission would open the possibility that such a decision is annulled before the Administrative Court. We regard that a more precise regulation of second-instance decision-making in these situations with an act of legal force no lower than that of the law, would eliminate the potential weaknesses of the appeal effectiveness in the EIA procedure. $^{26}$

\subsection{Additional Decision Review in Cases without the Right to Appeal}

It was indicated earlier in the paper that a decision deciding on approval of the EIA study is final administrative act. In other words, there is no second-instance administrative decision in this matter, but an administrative dispute may be initiated. The question arises on whether the request for review of a court decision, as an extraordinary remedy stipulated by the $\mathrm{ADA}$, can alleviate the absence of the second instance control of regularity. ${ }^{27}$

A party to an administrative dispute or a public prosecutor may submit a request for a court decision review. The public concerned may resort to this remedy only after the procedure on the complaint in an administrative dispute in which they participated as a party. The request for review of court decisions is decided by the Supreme Court of Cassation,

24 Rules of Procedure of the Government, Official Gazzette of the Republic of Serbia No. 61, dated 18 July 2006 - revised text, 69 dated 18 July 2008, 88 dated 28 October 2009, 33 dated 18 May 2010, 69 dated 24 September 2010, 20 dated 25 March 2011, 37 dated 3 May 2011, and 30 dated 2 April 2013.

25 GAPA, Art. 32 para. 4. See: S. Lilić, Upravno pravo/Upravno procesno pravo, Belgrade $2012^{6}, 527$.

26 For efficiency of the administrative appeal in Serbia See: D. Milovanović, M. Davinić, V. Cucić, "Efficiency of the Administrative Appeal (The Case of Serbia)", Transylvanian Review of Administrative Sciences, 37 E/2012, 95-111.

27 Art. 49 of the ADA. 
which has more authority than the Administrative Court. In this case, the Supreme Court of Cassation can not only abolish, but also reverse the decision that is challenged. The Supreme Court of Cassation, however, does not conduct the hearing upon this extraordinary legal remedy. That excludes the possibility of verifying the facts and circumstances that might be considered by the administrative authority on appeal. ${ }^{28}$

This extraordinary legal remedy is used only to review the violations of the rules of procedure which could have had the effect on the final decision. According to Art. 9, para. 2 of the AC, the public concerned is guaranteed the right to review a decision made by an administrative authority before a court or other independent and impartial body, in order to challenge the substantive and procedural legality. The request for reviewing court decisions, as an extraordinary legal remedy, does not allow an opportunity to challenge the substantive legality. ${ }^{29}$

\section{THE APPLICATION OF PROVISIONAL MEASURES AND THE EIA}

A final decision on approval of the EIA study represents a basis for the issuance of other administrative acts to the investor and a prerequisite for obtaining a building permit. The question arises on whether one can seek a stay of execution of the contested decision on the approval of the EIA study if obtaining building permits and the commencement of construction inflicts permanent and irreparable damage which is reflected in a complete, permanent and irrevocable destruction of natural values. In other words, must a decision on the approval of the EIA study be final administrative act, enforceable and legally valid as a final judgement passed by the Administrative Court?

One of principal obligations arising from the AC is the establishment of procedures that should guarantee "adequate, efficient ... provisional measures." ${ }^{30}$ Parties to the administrative procedure have a possibility to institute administrative proceedings and request a stay of deci-

28 The administrative authority shall issue a decision on the administrative matter which is the subject of proceedings on the basis of the facts established in the proceedings. See: Art. 192 para. 1 of the GAPA.

29 M. Drenovak-Ivanović, "Environmental Law in Serbia", Comparative Environmental Law and Regulation (eds. E. Burleson, N. Robinson, L. H. Lye) West Law, Thompson Reuters 4/2016, 45A:1-25.

30 Art. 9, para. 4 of the AC. For the ECJ, ECHR and Aarhus Convention Compliance Committee case law on Art. 9, para. 4 see: M. Drenovak-Ivanović, Pristup pravdi $u$ ekološkim upravnim stvarima, Beograd, 2014; M. Drenovak-Ivanović, Environmental Justice in a Comparative Context, "Justice Connections" (ed. P. Easteal), Cambridge Scholar Publishing, 2013, 282-307. 
sion execution. ${ }^{31}$ However, in case of emergency and when an appeal has no suspensive effect by law, and the appeal has not been finalised, the party to the administrative procedure may, before filing a complaint, ask the administrative court a stay of execution. ${ }^{32}$ The possible application of suspensory effect of the complaint is bordered by the condition that the execution of the decision causes damage to the complainant that can hardly be recovered. However, postponing the execution cannot inflict a greater or irreparable damage to the opposing party, and nor should it be contrary to the public interest.

The question then arises as to how the terms "greater damage" and "irreparable damage" are determined in environmental matters. In the absence of domestic practice, some of the criteria by which the court may order postponing the execution of the administrative act in environmental matters can be found in Recommendation No. R (89) 8 of the Committee of Ministers to Member States on Provisional Court Protection in Administrative Matters. ${ }^{33}$ According to the Recommendation, the court may order the postponement of execution: "When a court is seized of a challenge to an administrative act, and the court has not yet pronounced its decision". ${ }^{34}$ Further on, "Measures of provisional protection may in particular be granted if the execution of the administrative act is liable to cause severe damage which could only be made good with difficulty and if there is a prima-facie case against the validity of the act.",35

\section{CONCLUSION}

The EIA is a special administrative procedure which establishes an extent of potential negative impact of planned activities on the environment and human health. The analysis provided in this paper reveals five key elements of the EIA. The first element is screening, determining whether a proposed project requires an EIA procedure. The second element is scoping, determining the extent of issues of planned project to be considered in the EIA. The third element is preparation of the EIA study. The fourth element is involving the public in decision-making about the

31 See: Art. 23 of the ADA.

32 Z. Tomić, Komentar zakona o upravnim sporovima, Službeni glasnik, 2012², 451.

33 Recommendation No. R (89) 8 of the Committee of Ministers to Member States on Provisional Court Protection in Administrative Matters, adopted by the Committee of Ministers on 13 September 1989, available at: https://wcd.coe.int/com.instranet. InstraServlet . command $=$ com.instranet. CmdBlobGet\&InstranetImage $=2011090 \&$ SecMod $e=1 \&$ DocId $=702300 \&$ Usage $=2$, last visited $1^{\text {st }}$ January 2015 .

34 Ibid., Principle I.

35 Ibid., Principle II. 
first three elements. The fifth element is an administrative and judicial review of decisions made in the EIA procedure.

Under the current legal framework, the EIA procedure is conducted in three stages, with each stage organised as a special administrative procedure. Performed analysis indicates significant deficiencies in the EIA procedure, which in practice leads to cases where the third stage of the EIA is launched, with ongoing court proceedings concerning the disputed decision issued in the first or second stage. This further raises the possibility that a competent authority consent to the EIA study, which provides the operator with an opportunity to start implementing the project, and having the decision on the scope and contents of impact assessment reversed and the entire EIA process put back to the beginning.

A decision on the scope and a decision on the contents of the EIA study create a legal prerequisite for a decision on approval of the EIA study, by stipulating the basis of the analysis to be contained in the study. Although it is not directly decided in the first and second stage of EIA whether a particular activity may be allowed or not, acts issued in these stages shall provide a stand on the legal interest of the public concerned and operators, which is in accordance with the law and a prerequisite for entitlement in the third stage. Therefore, the EIA procedure can be viewed in two ways: either as three separate administrative proceedings, with a system of independent legal protection after each stage, or as a single administrative procedure. In the first case, the condition for launching the next stage would be not only the finality of the administrative decision from the previous stage, as provided for in the existing legal framework, but also the validity set by final judgement passed by Administrative Court. This would remove the disputability of the current EIA procedure regarding the effectiveness of the appeal. In the second case, the decisions in the first and second stage could be considered facts which are determined for purpose of making a decision on approval of the EIA study, without independence property, which may be the subject of an appeal or complaint initiated regarding a decision on approval of the EIA study. In both cases, the proceedings before the court should be speedy. Both possibilities require a revision of the current legal framework.

\section{REFERENCES}

Benson, J. F., "What is the alternative? Impact assessment tools and sustainable planning", Impact Assessment and Project Appraisal $4 / 2003$.

De Sadeleer, N. Environmental Principles: From Political Slogans to Legal Rules, OUP, 2002. 
Drenovak-Ivanovic, M., ,The Development of the Right to Public Participation on Environmental Matters as a New Concept of Administrative Decision Making in Serbia", Transylvanian Review of Administrative Sciences 44/2015.

Drenovak-Ivanović, M., "Environmental Law in Serbia", Comparative Environmental Law and Regulation (eds. Elizabeth Burleson, Nicholas Robinson, Lin Heng Lye) West Law, Thompson Reuters 4/2016.

Drenovak-Ivanović, M., Environmental Justice in a Comparative Context, "Justice Connections" (ed. Patricia Easteal), Cambridge Scholar Publishing, 2013.

Fisher E. et al., Environmental Law, OUP, 2013.

Lazarus, R. J. The making of Environmental Law, University of Chicago Press, 2008. $2012^{6}$.

Lilić, S. Upravno pravo/Upravno procesno pravo, Belgrade

Miller, K., Rawson, A., Act Environmental Law, Canberra 2009.

Milovanović, D., Davinić, M., Cucić, V., "Efficiency of the Administrative Appeal (The Case of Serbia)", Transylvanian Review of Administrative Sciences, $37 \mathrm{E} / 2012$.

Tišma, J., "Upravno-sudska zaštita prava na zdravu životnu sredinu", Bilten Vrhovnog Kasacionog suda 2/2015.

Tomić, Z. R., Upravno pravo - sistem, Belgrade $2002^{4}$.

Tomić, Z. R., Komentar zakona o upravnim sporovima, Službeni glasnik, $2012^{2}$. 